\title{
Young women choosing contraceptives Stories about information literacy practices related to evaluation and use of information sources
}

\author{
Af Johanna Rivano Eckerdal
}

\begin{abstract}
I artikeln presenteras delresultat från ett doktorandprojekt om informationskompetenspraktiker i svenskt vardagsliv: unga kvinnors (18-23 år) informationskompetenspraktiker när de väljer preventivmedel. Syftet är att förstå de unga kvinnornas perspektiv som det kommer till uttryck i deras berättelser om val och värdering av informationskällor om preventivmedel.
\end{abstract}

En metod inspirerad av narrativa intervjuer användes $i$ kombination med visuella verktyg. Resultat från tidigare intervjuer och observationer från ungdomsmottagningar användes också $i$ analysen, som gjordes med de analytiska ingångarna verktyg, meningserbjudanden, kognitiv auktoritet och ansatser till bedömning av trovärdighet.

Analysen visar att störst auktoritet gav de unga kvinnorna, genom tillit, till nära relationer. Mest användbara var barnmorskor och ungdomsmottagningar, som gavs auktoritet genom sin professionella utbildning. Kontroll och balans var de ansatser till bedömning av trovärdighet som användes.

Länken mellan barnmorskorna och staten diskuteras liksom den varierande förståelsen av källkritisk

Johanna Rivano Eckerdal, PhD student in library and information studies. Department of Arts and Cultural Sciences, Lund University (Johanna.Rivano_Eckerdal@kultur.lu.se) vokabulär. Slutligen görs en kritisk granskning av den dominerande uppfattningen att informationskompetenspraktiker endast relaterar till text samt den underförstådda kausala relationen mellan informationskompetens och agerande.

\section{Introduction}

The practice of choosing contraceptives is of vital importance for young women. Surrounded by advice from friends, partners and relatives, discussion forums and blogs, information from public authorities and midwives, young women do make their choices. But how can we understand the balancing act of valuing, comparing, and selecting, as the young women themselves understand it? The purpose of this article is to gain an in-depth understanding of young women's information literacy practices from their point of view as expressed in their stories about how they chose a contraceptive. The following question has guided the research: When telling their stories about how they chose a contraceptive, what are the information literacy practices the young women talk about, related to evaluation and use of information sources? This question illustrates a wish to investigate information literacy practices outside the dominant settings of education, libraries and workplaces (Lloyd \& Williamson, 2008). A related purpose of the article is therefore to develop the empirical basis of information literacy research.

Young people's evaluation of information on their sexual and reproductive health has been pointed out 
as a missing research topic within library and information studies, LIS, (Pierce, 2007, p. 83). A crucial element of evaluation, credibility assessment, has been studied within LIS as embedded in the information seeking process (Hilligoss \& Rieh, 2008) and as an information literacy practice by Francke et al. in their study of upper secondary students credibility assessment (2011). Francke and her co-authors found that students, in their study, adopted six different strategies: authorship, references, applicability, currency, media properties, genre, rhetoric and social commitment. Those were aggregated to four nonexcluding approaches toward credibibility assessment: control, balance, commitment and multiplicity. When students understood the assignment goal as finding the right answer, control was achieved by following certain rules and checklists: "the decontextualised nature of these checklists invites interpretations based on a dichotomy; credible or not credible" (Francke et al. in press). Balance was of two kinds, the first about finding several concordant sources and the second about finding sources with different viewpoints and balancing between them. The credibility of single people or groups with a mission to improve conditions for many, such as NGOs', or with activities that affect many people and thus supposedly with social responsibility is based on commitment. Finally, credibility from multiplicity comes to sources that are created in collaboration and thus allowing many perspectives (Francke et al., 2011). These approaches will be discussed in the article.

Sweden was early to offer public sexual counselling. Sexual education programs are mandatory in public schools since 1955. The Swedish public health sector addresses issues related to both adult and adolescent sexual health, including prevention of unintended pregnancies and abortions as well as sexually transmitted infections, STIs (Ekstrand, 2008, p. 63). The attitude towards adolescent sexuality is supportive from both authorities and organisations such as $\mathrm{RFSU}^{1}$ and RFSL ${ }^{2}$. Although not mandatory, many municipalities have a youth centre helping and advising young people on sexual and social life, e g counselling about and prescribing contraceptives (Christianson, 2006). Most youth centres are members of The Swedish Society for Youth Centres, a society with goals shared by all their members. To qualify as a member centre the staff must include a midwife, a social worker and/or a psychologist and a physician (FSUM, s d ). It is mostly young women who turn to youth centres (FSUM, s d). All of the young women in this study had visited a midwife at a youth centre for counselling about contraceptives.

\section{Theoretical framework}

Empirical and theoretical contributions have convincingly shown that information literacy must be understood in context (Francke et al., 2011; Limberg et al., 2008; Lloyd \& Williamson, 2008; Sundin \& Francke, 2009; Talja, 2005; Talja \& Lloyd, 2010; Tuominen et al., 2005). General definitions and standards of information literacy have been criticized by their blindness to context (Tuominen et al., 2005, p. 330). The critique arises from different theoretical perspectives sharing a strong emphasis on the social character of learning and hence of information litera$\mathrm{cy}$, as learning happens when information literacy is practised. Information literacy practices are complex and involve seeking and using information. Information literacy practices and information seeking and use are interrelated concepts (Limberg, 2010). In this study focus is on the evaluation and use of information sources, a crucial part of information literacy practices.

A sociocultural perspective on learning (Säljö, 1999; Wertsch, 1998) is applied in this study. Learning is, according to this perspective, a fundamental part of living and a social activity. Roger Säljö (1999) argues that over time people have developed physical and intellectual tools for doing things. As tools are developed and used in specific social and cultural settings, being knowledgeable means having knowledge about the tools used in specific times and places (ibid). Information literacy refers then to practices that people are involved in, practices that are influenced by the tools used at the same time as the tools are given meaning in the interactions (Sundin \& Francke, 2009). Tools mediate knowledge and in anyone situation certain ways of using a tool are favoured or approved while others are silenced or regarded as improper. Tools empowers or enables, as well as constrain or limit actions (Wertsch, 1998, p. 38).

The tool metaphor of the sociocultural perspective fits well with the analytical concept of affordances (Gibson, 1977; see also Wertsch, 1998, p. 29). Affordances can be seen as the ways by which tools become meaningful for someone in specific situa- 
tions, "the opportunities for action offered by the real world" (Sadler \& Given, 2007, p. 117). Ronald Day (2011) proposes the concept of affordances as a way of overcoming what he regards as problems in research about information use. Even a constructionist theoretical framework research is, according to Day, often trapped in ideas about mechanistic causality based in behaviouristic and scientific ways of thinking (ibid, pp. 79-80). Day suggests affordances, as more appropriate (ibid, p. 80). Focus is then transferred from effects of mechanistic causality to the affects of interactions (ibid, p. 81). With a situated view on learning and information literacy practices it is more adequate to talk about the affordances available in a situation, e g when choosing a contraceptive, than to concentrate on the information sources or the user in isolation from each other. The experiences described here may help us understand what affordances may be available for a young woman choosing a contraceptive in Sweden today.

Before moving on to the method and results of the study, yet another analytical concept needs to be introduced - the concept of cognitive authority. In the present study information literacy practices is operationalized by means of carrying out source criticism, specifically how different information sources are evaluated and used before the contraceptive choice is made. In his analysis of the social construction of knowledge, Patrick Wilson (1983) introduces the concept of cognitive authority to describe how we learn about things we have no first-hand experience of. Cognitive authority is defined as a non-absolute, graded relationship including two or more people (ibid, p. 13). You are a cognitive authority in a specific sphere, with a specific magnitude. A cognitive authority is credible, someone you want to have influence on your way of thinking (ibid, p. 15). The concept thus fits with a sociocultural understanding of knowledge as produced and shaped in social interaction. Wilson (1983) explains why we hold others as cognitive authorities. From birth we are influenced by our surroundings, the specific time and place that we live in shapes us; we develop "a stock of authority beliefs "(ibid, p. 125). Occupational specialization or formal education are bases for recognising authority. Reputation, be it reputation among peers or transferred from another cognitive authority is also important to recognize cognitive authority. Intrinsic plausibility, that is finding a specific source useful and enlightening on several occasions, because it fits with what you already believe, also plays a role in recognizing cognitive authority.

\section{Method and analysis}

The methodological framework developed is inspired by the narrative interview method (Bates, 2004; Jovchelovitch \& Bauer, 2000; Mishler, 1986), which is presented in depth elsewhere (Rivano Eckerdal, forthcoming).

The empirical material of this study consists mainly of the conversations and the information maps (Elovaara et al., 2006) and information source horizons (Savolainen \& Kari, 2004; Sonnenwald et al., 2001) produced during five interviews. The author met all five participants two to seven months prior to the interviews: two participants had been individually interviewed and three participants had taken part in group-interviews. The five young women, $18-21$ years old, in contact with a youth centre, were asked to participate. They were informed that participation was voluntary, material being treated confidentially. One had dropped out of upper secondary school and was working but going back to school again. Three had just finished upper secondary school; one of them working, the other going abroad and the third applying for higher studies. One was studying at a university. Four of the interviews took place at different youth centres in the south of Sweden, and one at the author's workingplace. The interviews and transcriptions were carried out by the author. The interviews lasted from about 40 minutes to one hour. The pseudonyms Anna, Lisa, Mia, Paula, and Sofia are used in the article. The quotes have been translated to English by the author. The study was approved by the Regional Ethical Review Board of South Sweden

The stories told by the young women are emphasized (Mishler, 1986). The activities they were invited to engage in, drawing of maps and horizons and using the deck of cards, were designed to promote participation, involvement and bring about their telling. The interviews are transcribed so that words heard and sounds of activities are registered to bring forth as much as possible of the situation. The interviews were structured as follows: First, the young women were asked to tell their story about the information sources they used before choosing a contraceptive. They were given a deck of cards with suggestions of 
sources to be used as memory triggers. While telling the story they were asked to use a paper and pen and draw or write the sources on the paper (map of information sources). Second, they were asked to use another paper and arrange the sources according to their usefulness and importance to make the choice (information source horizon). Finally, they were asked a set of questions. In line with the narrative research interview approach introduced by Mishler (1986) it was foreseen that the interviews would create situations that facilitate reflection and the ability to put experiences in words for the first time. The interview as a whole is an answer to the questions(s) asked. No part of the empirical material is therefore perceived as more "true" or valid than another.

The stories told during the interviews have been analysed by iterative close readings of the transcripts from the five interviews and both information maps and information source horizons that were made during the interviews. The material was structured in themes of relevance to the research question. Findings from previous meetings with young women and midwives reported elsewhere are also used in this study (Rivano Eckerdal, 2011; Rivano Eckerdal, in press). The following analytical concepts are used in the analysis: Tools and affordances for analysing what information sources the young women have engaged, cognitive authority for analysing how authority is ascribed to information sources, and the four approaches for assessing credibility suggested by Francke et al. (2011) to analyse the credibility assessment of web sources that the young women engage with. Results are presented by following the themes that were analyzed in the stories told by the young women about the different information literacy practices they got involved in when choosing a contraceptive.

\section{Results}

Since we met for the first interview the five young women had chosen and started to use a contraceptive. All five were pleased with how they went about finding information before making the choice. Three of them: Anna, Mia, and, Paula were satisified with the contraceptive thay had started to use. Lisa and Sofia had experienced side-affects ${ }^{3}$ and Lisa was therefore going to change from one sort to another. As we had met before in another kind of interview I explained the set up for this one and showed the drawing-block and pens that they were going to use. Then I asked them to tell their stories.

\section{Midwives at youth centres}

Youth centres were important to the young women I met. Particularly the centres' easy access and the young women's feeling of being welcome and well treated there, like Mia said: "It was just, I got a welcoming, you know, like it wasn't strange that, like those who work here they don't think that anything is strange, you don't get starred at or something, like you'd imagine that it could be embarrassing with them". Some of them had been at the centre prior to their own visit, accompanying a sister or a friend. Others learnt about the centre as they visited school or from their teachers', school nurses' or mothers' information. The youth centres exerted authority in contraceptives because the people working there were trained and had long experience in counselling and prescription: "Well it feels like at the PINFOmeeting [group-information about contraceptives at a youth centre], that were midwives who knew what they were talking about, who have been working with this for a long time and really know what they are talking about" (Lisa). The youth centres and the midwives were important affordances, in many cases introduced to the young women in settings generally holding a cognitive authority, the schools. Compared to teachers and sexual education within schools, the midwives and the youth centres, held a higher degree of cognitive authority with regard to sexual health.

\section{Most important versus most useful information source}

Anna, who had not used contraceptives said that "it's hard to somehow take the step". A conversation with friends at a cafe table in the sunshine was a turning point. Her friends talked about diseases and one of them said that she had taken a chlamydia-test. Anna decided to do the same. She had begun a new relationship and her boyfriend wanted them to use contraceptives, something she had not done in her previous longterm relationship. Anna had not become pregnant and was wondering whether she could get pregnant at all. Her boyfriend was not happy with the situation. A friend became pregnant a few months ago, having an abortion. "So that, that's what maybe opened my eyes, that she just, I don't wanna go through that." When the midwife, in connection with the chlamydia test, mentioned how easy it is to get pregnant at her age Anna decided to use contracep- 
tives. She had been afraid to gain weight. To Anna it was a combination of factors that at a certain point made her decide to use a contraceptive. She had not lacked information about the importance of contraceptives but it had mostly been associated with unwanted side-affects and not related to an understanding of her own body as a fertile one (cf Ekstrand, 2008).

The young women relied mostly on people close to them, friends or family. Sofia put it like this: "but, without mum, then the first time or maybe my boyfriend the second time, I had never come up with the idea". Friends or sisters conveyed their personal experiences, valuable yes, but "taken with a grain of salt"(Mia; Sofia) as theirs could reflect different experiences. This distinction between most important and most useful sources can be fruitfully analyzed following Wilson's ideas about cognitive authority and trust (1983, pp.21-25). The midwives with their professional training and a positive attitude towards sexuality, were viewed as cognitive authorities but the most important people were those close to the young women. This became apparent when they told their stories. The conversation with the midwives offered valuable opportunities to ask questions. However their trust in peers or family was crucial for initiating the contact with the youth centres.

The importance of close relations was examplified in Mia's story. When I asked her to describe her most important sources to make the information source horizon, she answered that it is different now, compared to earlier in her life. Mia was puzzled about how to deal with present and past when making the horizon. I suggested that she use two papers to make two information source horizons, but she decided to use one and divide it into two sections: her horizon when she was 13-16 years old and the present time horizon. Then she wrote down the information sources available to her in the past and the present ones while she talked about it:

"M: Eh, then I know that I had my 'plastic sister', she was very close

[left out part where Mia describes what she means by 'plastic sister': her dad's new wife's daughter] M: Yes, exactly, uh, she was, she is a year older than me, I have no contact with her now. Because they have divorced and then

$\mathrm{J}: \mathrm{Mm}$
M: But she was a year older and sort of one step ahead of me

$\mathrm{J}: \mathrm{Mm}$

M: So I could go after her, or so

J. Mm

M: Eh, then, eh. I have to think now, even her mother then, my dad's wife that is, was very helpful

$\mathrm{J}: \mathrm{Mm}$

M: Shall I write 'plastic mother 'too? (laughter)

$\mathrm{J}: \mathrm{Mm}$

M: Because I could talk to her in a completely different way than I can with my mom

$\mathrm{J}: \mathrm{Mm}$

M: precisely, maybe, because there was this little distance " (Mia)

The procedures and decisions to produce an information source horizon opened up for Mia a path to tell the story about how her personal network changed in the last few years. Mia was not a very verbal person. It is unlikely for that story to unfold if the interview was carried out without the visual aids. Mia knew about the youth centre by following her 'plastic sister' there and was sure it was a place where she would be treated well, a place in which no one would stare and make her feel embarrassed. A place to return to. But Mia's father and 'plastic mother' had divorced. Mia had no contact with her 'plastic sister', her 'plastic mother', or her other siblings. When it came to birth control she did not have anyone close to trust but her boyfriend. Mia had not used any contraception. She suspected she was pregnant and therefore came to the youth centre and, when the midwife suggested it, decided to start with a contraceptive. Mia's story shows the vulnerability implied by large changes in the personal network when close people become distant or disappear. In Mia's case the youth centre was an affordance introduced to her by her trusted 'plastic sister' who disappeared from her vicinity, perhaps delaying Mia's own contact with the youth centre.

\section{Midwives as representing society}

Once in contact, the midwives were also trusted. Two of the young women connected their trust in the midwife and trust in society and citizenship. Anna put it like this:

“A: But they are supposed to know, you cannot just come here and then, and not believe in it be- 
cause then you just don't believe in society, that's how I feel

$\mathrm{J}: \mathrm{Mm}$

A: like their education and this whole thing. So, that it's something you as a citizen have to feel that. No, but this is safe and like that, that they want to help you and all." (Anna)

For Anna, the youth centre was trusted as a cognitive authority thanks to the professional training of the staff. Sofia talked about the youth centre as well as the organization RFSU:

"S: Because it's, it's like that's why it exists. I think both of them are like governmental, agencies. And they are sort of made to give us information about this

$\mathrm{J}: \mathrm{Mm}$

S: and because of that, I trust them because they would not sit there and lie." (Sofia)

In Sofia's story the youth centres represented both state and society, their task being to inform young people about contraceptives. This functioned as warranty for the information. The positive attitude they had about the state in their "initial stock of beliefs" was then transferred to the midwives.

\section{Source criticism and information seeking equals searching the net}

The young women all said that they use Internet both to find things and check up what they have heard.

Four of them did so before choosing a contraceptive. Lisa said: "I often look on the Internet when I want information about something". Internet was prominent in their information literacy practices, reflected in their expectancies to find relevant information there. Anna said: "it would have been really strange if the youth centre hadn't been online".

Anna, Lisa and Sofia were in theoretical programs in upper secondary school and said that source criticism, a term they relate to sources on the Internet, was used in school assignments in different subjects. They were trained in and comfortable with using source criticism vocabulary like source criticism, being critical, trustworthy, sources, seeking information. Mia and Paula, on the other hand, not trained in the same way, were not as familiar with the vocabulary.
The usual way to seek information was to google a word, such as "contraceptive" or one particular kind of contraceptive, like "the Pill". Then they browsed the hit-list to decide what pages to go to. One exception was Paula who said that: "I didn't search, I didn't google or anything", but instead used the webpage from the youth centre.

All but one had read what people said in forums online without active participation. Nevertheless, it is argued here that, by reading and sharing experiences they were actively using the affordances offered by the websites.

Only Mia did not use the Internet at all before choosing a contraceptive. In retrospect, she was surprised and said that today she would definitely use the Internet. During the interview she became aware of the amount of information on contraceptives on the Internet. After looking at the deck of cards with suggested information sources she said: "That was a lot!" and laughed. Mia dropped out of secondary school during the first year and was working instead. At work she designed a website so she was not unfamiliar with the Internet.

The Internet was thus an affordance for four of the young women when preparing their choice of a contraceptive. However they did not approach the diversity of sources by means of balance or multiplicity as described by Francke et al. (2011). Mainly they sticked with the well-known sites from the youth centres, "umo.se" (the national youth centre on the web), and the organisations RFSU and RFSL. Contraception being an unfamiliar subject for Paula, it was important for her to use trusted sources and the youth centre, recommended by her mother, received her mother's cognitive authority by transference.

\section{Criteria for assessing credibility}

The criterion used to assess credibility of a website was firstly that of concordance; if the same information was found on several places its credibility raised. Association with authority, found out by looking at the name of the page or the publisher, was another criterion. These criteria fit into Francke's et al. balance and control approaches (2011). Proper language with no misspellings was, according to the young women, an important criterion for credibility. On the web, expressions and style that were seen as youthful had low credibility in comparison to the 
high credibility that was given to the young women's friends. Paula's use of language was personal, reflecting source criticism vocabulary only to some extent:

"P: You know, there, you usually see quite quickly when it isn't true. It's (then and sort of) terribly far out and then when you somehow know that they're talking through their hat.

J: In what way, like, how can you see that?

P: (It's) how they write

J: Yes

P: you see when people misspell

J: Yes

P: first of all, very much, like a lot, that you cannot really trust that it is

J: No

P: or that it looks very, too carelessly written. Like as a blog, almost

J: Yes

P: a bit like this:" I think", "today happened"

$\mathrm{J}: \mathrm{Mm}$

$\mathrm{P}$ : Then perhaps you cannot really rely entirely on

it either

$\mathrm{J}: \mathrm{Mm}$

P: It's a bit like, this is like a book of facts. You get to know those a bit more difficult, yeah but, difficult words." (Paula)

Paula was looking for proof of truth or falseness, her dichotomic evaluation based on an understanding of information as either credible or not. She was apprehensive about getting information as in Francke et al:s control approach for assessing credibility (2011). However, she used several assessment criteria, bringing the structure of the website into it.

\section{Understanding not credible sources}

Sofia was disappointed for not being informed about possible side-affects of using an implant, before she had one herself and experienced side-affects. She said that she usually trusted information when repeated by many sources, her judgement about credibility being based on concordance, fitting with a balance approach. When looking for information about implants she came across a discussion forum, mentioning two comments that stood out:

"And then it was suddenly two that sort of was written very much like in, you know young language, and then just: “ I can’t take this any more and it's fucking shit" and like that, you know. And then you cannot see it as just as credible as someone who, like, who signs with mid-. It can, it may well be bullshit on the Internet as well, but. But it feels more credible if there are many, many, who say the same thing." (Sofia)

This was the only place she found in which negative aspects were discussed. The language was coarse and typical of teenagers. The comments thus fulfilled two criteria for not being credible. However, in retrospect, she noted that this was the only information she found about problems with using an implant. Otherwise information she got was based on statistics: most implant users do not experience severe side-affects. Sofia turned out to be an exception. That the website from the medical company that produce the implant was positive was self-obvious to her. But she didn't recall the midwife mentioning the possibility of experiencing severe side-affects. She felt being treated like a child, not receiving all relevant information. "I'm big enough for them to talk to me like a grown-up person, but it would have been nice to know, when it starts to hurt one month later; what, what's this?" The midwife was a trusted source, like society. When Sofia felt mis-informed by one of its representatives it impinged on her trust on society at large.

On the other hand, Anna had heard a lot of bad things about contraceptives and was hesitant to use one. When the midwife said that most of the young women she met were content with their contraceptive, Anna decides to try." There's so many that are pleased with it, you know, so why shouldn't I be? " When we met she was on the Pill and was satisfied. These examples show inadequacies of the control approach on credibility of information on complex matters illustrating how searching for correct answers might become an obstacle empoverishing the understanding of the situation.

\section{Understanding trust and credibility}

A basic issue in discussions about source criticism and evaluation of information and information sources within educational settings is their credibility, the implicit argument being that a credible (trovärdig in Swedish) source is one that you trust (lita på in Swedish). Credibility opens for trust and use. However, in this study trust and credibility were not understood as having similar weight. There was no 
agreement on their understanding of the concepts. Paula said that if something is credible or if she trusts it are sometimes different things. Anna put it like this:

"Many, not many, but there are many who have sort of this ability to seem really sure about something, uh, and, but then maybe time and time again you have been proven that this person wasn't on the right track after all." (Anna)

To Anna credibility could be deceptive and might be labelled as intrinsic implausibility. Her understanding was based on personal experience of the information source. Lisa on the other hand said that: "So it's, it could be credible if somebody informs about, uh, birth control. But then maybe I don't trust it, because it doesn't suit me or, you know." A source could then be credible but not suitable, or, in LIS terminology, relevant. Her understanding did not rely upon personal experiences as Anna's. To Mia credibility was related to belief as opposed to knowledge; credible weighed less than trusted. Finally, Sofia understood credibility in relation to safe:

“S: Credible doesn't feel just as, as safe.

$\mathrm{J}: \mathrm{Mm}$

S: Credible is more like, yes it could well be like this.

$\mathrm{J}: \mathrm{Mm}$

S: It is not completely unlikely." (Sofia)

To sum up the important affordances identified in the young women's stories about information literacy practices they engaged in when choosing a contraceptive were friends, family and partners, visits at youth centres, midwives, the Internet and specifically the homepages of the youth centres and the organisations RFSU and RFSL, and the virtual youth centre, umo.se. Other Internet sources were used only to some extent. The concepts trust and credibility were understood in various ways. The evaluation of the information sources reflected source criticism instructions as normally given in schools, but also showed the importance close relations have for establishing cognitive authority and trust.

\section{Discussion and conclusions}

This article focuses on young women's information literacy practices from their point of view, in stories about the information literacy practices they got involved in when choosing contraceptives, specifically their use and evaluation of information sources. The concepts of affordances and tools were used to analyze the information sources engaged by the young women when choosing contraceptives. Their evaluation of information sources was analysed with the concept of cognitive authority and, regarding web sources, by their credibility assessment.

As shown in a study by Sundby et al. (1999) the young women in the present study knew that it was important to use contraceptives. As in the studies by Ekstrand (2008), fear of unwanted side-affects and limited knowledge about fertility were found to be reasons for not using contraceptives. According to the present study, when choosing a contraceptive, information literacy practices started with close, trusted people. At a certain point a step was taken and the young women engaged with midwives at the youth centre. The input they got from trusted people, like friends, family and partners, was important. Trusted, close relations are pictured as most important, being crucial to engage with the midwives, viewed as most useful for choosing contraceptives. Lacking support from close relations concerning sexual health led to a vulnerable situation. The personal network thus is an affordance that enables or limits the young women's willingness to contact the youth centres.

The midwives were attributed cognitive authority as professionals and became trusted sources. In the stories connections were drawn to trust in society. To some of the young women being a citizen implied to trust the midwives. In Sweden the notion of "Folkhem", the peoples home, is still very influential (Frykman, 2004, p.130; Johansson, 2004, p. 117). There is generally a positive attitude towards institutions and the state. Authorities are mostly considered and expected to be benevolent. Other ways of perceiving authority may become an obstacle in the interaction. In the previous meetings with young women and midwives, a young woman distrusted the information given by the midwife, complicating the situation. It was difficult for them to go on. The young woman was critical towards the state and authorities. To a certain extent, as a researcher, towards me. She interrupted the interview and suggested that we continued on another occasion. Later she chose not to meet me again, explaining it by saying that she did not fit in. Attitudes towards the state matter and 
may be discussed in relation to how cognitive authority is based on an initial stock of beliefs (Wilson, 1983, p.125), as well as Francke's et al. commitment approach (2011). The extent to which the state is viewed by the young women as "doing good" or not affects their credibility assessment. Their information literacy practices thus have political dimensions (Andersen, 2006; Elmborg, 2006; Kapitzke, 2003). Accordingly the association between the youth centres and the state can be understood as an affordance that, depending on the initial attitude towards the state or society, empowers or limits the young women.

The young women in the study who went through a theoretical program in upper secondary school were familiar with a source criticism vocabulary. In the stories source criticism refer to the Internet, mainly understood in ways corresponding to Francke's et al. control and balance approach (2011), the traditional ways of understanding source criticism within schools. Main criteria were concordance, authority of the source and correct use of language. Information seeking is then mainly a question of finding the correct answer. If the young women were trained in the use of all four approaches, it would mean they were not using their repertoire. However, it is more likely that the approaches they adopted were the ones they were trained in. Research by Francke et al. and other studies of information literacy practices within the educational sector were conducted in schools and exemplary classes with regard to work with information literacy practices within the school context. The young women here were on the other hand not selected according to the school they had attended.

Hilligoss and Rieh's carried out a study with the aim to construct a framework for credibility assessment (2008). When describing credibility construction they found that most participants construed credibility as trustworthiness, that the source and the information can be trusted (Hilligoss \& Rieh, 2008, p. 1474). In the present study trust and credibility were however found to have various understandings for the young women. Credibility was not perceived as trustworthy by some of them, while credibility was perceived as stronger than trustworthiness by others. Hilligoss and Rieh's study was done in English while the present study was done in Swedish. The differences may be due to linguistic distinctions. Nevertheless as the understandings of trust and credibility, in the present study were found to be equivocal, questions are raised about source criticism training. If source criticism training in schools aims at finding credible sources and the understanding of credible goes uncommented but is varying and ambiguous, the outcome is confusing. Assumptions that source criticism training will prepare for wise reasoning in everyday life settings are challenged. And a highly regarded tool within school practices, source criticism and its vocabulary, might be equivocal.

In this study, young women used a limited set of approaches to source criticism that influence their evaluation in this setting. The way in which the Internet becomes meaningful to the young women is to a high degree shaped by a control approach, which limits their use of sources. The variety of sources on the Internet is not used. The multiplicity approach could in this case be fruitful for discussing how people evaluate and deal with statistically generated information. More likely than not, presented with statistical information describing how well the majority react to contraceptives, the young women will include themselves as belonging to the majority. If they, like Sofia, prove to belong to the minority experiencing side-affects they might feel desinformed. This seems to be a collateral affect of statistically generated information. Discussing different understandings of knowledge claims coming from a majority or a minority could be a starting point for expanding the young women's approaches to crediblity assessment.

On the other hand, the emphasis on control in the young women's stories can be related to their understandings of contraceptives as ensuring safety. From their point of view the evaluation was fitting and worked well for the purpose of choosing contraceptives.

In the young women's evaluation arises an association between the midwives' authority and the state. The midwives and the youth centres activity are advanced as supporting and helping young people (FSUM, s d). Affordances offered as empowering may in fact be understood as controlling. This ambiguity was discussed in relation to the concept information literacy in the specific context of information literacy practices regarding midwives' counselling at youth centres (Rivano Eckerdal, 2011). The ambiguity is here also analyzed as part of the young women's stories about how they evaluate the midwives and the youth centres. 
The findings have implications for training information literacy practices within schools. It would be valuable if young people did experience a repertoire of approaches to evaluate information sources. Engagement in discussions about the use and evaluation of a variety of information sources and in relation to many kinds of sources might be useful. Thereby young people would gain a vocabulary adequate within school settings, as well as confidence and a set of approaches useful in settings outside the school. This would be particularly valuable in situations in which young people not are supported by their close relations.

The assumption behind arguments on information literacy, stipulating a causal relation between knowledge about information and information sources and how people act, does not hold in this material. Arguments put forth about the importance of being information literate for the good of society and the individual imply that, if well-informed, people will act according to the information given. This assumption has been challenged in relation to both reproductive health information (Pierce, 2007, p.64) and environmental information (Haider, 2011). In writings about information literacy there is still not seldom an undertone of causality that is not supported by the findings of this study. The young women's non-use is not due to lack of information.

One issue brought up by researchers adhering to alternative approaches to information literacy (Sundin, 2008) relates to how traditional approaches on information literacy are based on scholar and text oriented views on information (c.f Kapitzke, 2003; Limberg; Sundin \& Talja, 2009; Lloyd, 2007; Tuominen et al., 2005). When information literacy practices are understood as situated, affordances of a situation that people are involved in may be texts. But the text will most definitely be engaged with and accompanied by other kinds of affordances, other kinds of 'material', other kinds of tools. If information sources are only understood as textual objects the understanding becomes limited and many actions unintelligible. By adopting a situated perspective on information literacy practices, focus on the interaction taking place and its complexity is emphasized. If information literacy and its training is understood as relating to texts only, the training will have little or no bearing on everyday life information literacy practices. On the other hand, if understood as situated, it holds potential for developing the political implications.

The results show convincingly how youth centres and their easy access and welcoming atmosphere, and the midwives working there are highly valued affordances to young people. It is important to maintain that and to continue making the centres known to those not familiar with youth centres, e g by visiting schools and being present on the web. A suggestion based on the findings is to avoid dismissing information sources as untrustworthy or not useful but instead to bring them into the conversation, finding out what meaning they have for the young women. Another result that might prove be useful to midwives is to be aware that statistically based information may be understood very differently by people.

This study has contributed to LIS research by developing the empirical basis and widening our understanding of information literacy practices in an everyday life setting from young women's perspective. Developing and using a methodology that invited participation and engagement was key to the richness of the material.

In a coming article I will look into how interacting with different information sources influences the young women's sexual identities, how contraceptives as affordances in themselves and as information sources (about contraceptives), become meaningful to them. Other issues worth of further investigation are the information literacy practices about birth control that young men engage in, and the information literacy practices of those that e g due to distrust, do not come to local youth centres and what role the virtual youth centre may play then.

\section{Acknowledgements}

The author wishes to thank warmly the young women that participated in the study for sharing their experiences with me. I would also like to thank the Library and Information Studies research seminar at the Department of Arts and Cultural Sciences at Lund University and the two anonymous reviewers for their helpful comments that improved the text. 


\section{Notes}

1. RFSU, Riksförbundet för sexuell upplysning [the Swedish Association for Sexuality Education]

2. RFSL, Riksförbundet för homosexuellas, bisexuellas och transpersoners rättigheter [the Swedish Federation for Lesbian, Gay, Bisexual and Transgender Rights]

3. In line with Ronald Days' suggestions of using affects instead of effects when researching information use (2011, p.81) I will throughout the article use side affects instead of the correct term side effects. Hereby emphazising that using contraceptives is a complex endeavour where the use may be understood and experienced in various ways. Experiencing the use of contraceptives is not a matter of mechanistic causation but one of human beings making sense of using a technology on their bodies.

\section{References}

Andersen, J (2006). The public sphere and discursive activities: information literacy as socio-political skills. Journal of documentation, 62 (2), 213-228.

Bates, JA (2004). Use of narrative interviewing in everyday information behavior research. Library \& Information Science Research, 26, 15-28.

Christianson, M (2006). What's behind sexual risk taking? Exploring the experiences of Chlamydiapositive, HIV-positive, and HIV-tested young women and men in Sweden. Umeå: Umeå universitet. (University of Umeå Ph.D. dissertation.)

Day, RE (2011). Death of the user: reconceptualising subjects, objects, and their relations. Journal of the American Society for Information Science and Technology, 62 (1), 78-88.

Ekstrand, M (2008). Sexual risk taking: perceptions of contraceptive use, abortion \& sexually transmitted infections among adolescents in Sweden. Uppsala: Acta Universitatis Upsaliensis. (University of Uppsala Ph.D. dissertation.)
Elmborg, J (2006). Critical information literacy: implications for instructional practice. The journal of academic librarianship, 32 (2), 192-199.

Elovaara, P, Igira, FJ, Mörtberg, C (2006). Whose participation? Whose knowledge? exploring PD in Tanzania-Zanzibar and Sweden. In: Proceedings of the ninth conference on Participatory design: Expanding boundaries in design, Trento, August 1-5 (pp.105-114). New York: ACM.

Francke, H, Sundin, O \& Limberg, L (2011). Debating credibility: the shaping of information literacies in upper secondary schools. Journal of Documentation, 67(4), 675-694.

Frykman, J (2004). Swedish Mentality: Between Modernity and Cultural Nationalism. In: K Almqvist \& K Glans (Eds.), The Swedish Success Story? (pp. 121- 132). Stockholm: Axel \& Margaret Ax:son Johnson Foundation.

FSUM Föreningen för Sveriges ungdomsmottagningar. (s.d.) Policy programme for Sweden's youth centres. Retrieved 14.4.2011 from WWW: http:// www.fsum.org/fsum/wp-content/uploads/2011/02/ policyen.pdf

Gibson, JJ (1977). The theory of affordances. In R Shaw \& J Bransford (Eds.), Perceiving, acting, and knowing: toward an ecological psychology. Hillsdale, N J: Erlbaum.

Haider, J (2011). The environment on holidays or how a recycling bin informs us on the environment. Journal of Documentation, 67(5), 823-839.

Hilligoss, B \& Rieh, SY (2008). Developing a unifying framework of credibility assessment: construct, heuristics and interaction in context. Information Processing \& Management, 44(4), 1467-1484.

Johansson, R (2004). The construction of swedishness. In K Almqvist \& K Glans (Eds.), The Swedish Success Story? (pp. 109- 120). Stockholm: Axel \& Margaret Ax:son Johnson Foundation.

Jovchelovitch, S \& Bauer, MW (2000). Narrative Interviewing. In M W Bauer \& G Gaskell (Eds.), Qualitative researching with text, image and sound: a practical handbook (pp. 57- 74). London: Sage. 
Kapitzke, C (2003). Information literacy: a positivist epistemology and a politics of outformation. Educational Theory, 53 (1), 37-53.

Limberg, L (2010) Information Literacies at the intersection between Information Seeking and Learning: contexts and values. Introductory paper for the Information Literacy Research Seminar at CoLIS, London, June 23, 2010. Retrieved 2 July, 2011 from: http://hdl.handle.net/2320/6536

Limberg, L, Alexandersson, M, Lantz-Andersson, A \& Folkesson, L (2008). What matters? Shaping meaningful learning through teaching information literacy. Libri 58, 82-91.

Limberg, L, Sundin, O \& Talja, S (2009). Teoretiska perspektiv på informationskompetens. [Theoretical perspectives on information literacy.] In J Hedman \& A Lundh (Eds.), Informationskompetenser: om lärande i informationspraktiker och informationssökning i lärandepraktiker [Information literacies: on learning in information practices and information seeking in learning practices] (pp. 36 - 65). Stockholm: Carlsson.

Lloyd, A (2007). Recasting information literacy as sociocultural practice: implications for library and information science researchers. In Proceedings of the Sixth International Conference on Conceptions of Library and Information Science: "Featuring the Future". Information Research, 12(4) paper colis34. Retrieved 16.4.2011 from WWW: http://InformationR.net/ir/12-4/colis34.html

Lloyd, A \& Williamson, K (2008). Towards an understanding of information literacy in context: implications for research. Journal of Librarianship and Information Science, 40(3), 3-12.

Mishler, EG (1986). Research Interviewing: context and narrative. Cambridge, Mass: Harvard University Press.

Pierce, JB (2007). Research directions for understanding and responding to young adults sexual and reproductive health information needs. In: M K Chelton \& C Cool (Eds.), Youth information seeking behaviour II: context, theories, models, and issues (pp. 63-91). Lanham Md: Scarecrow Press.
Rivano Eckerdal, J (fortcoming). A personal bodyguard: narrative interviews in the study of information literacy in everyday life settings.

Rivano Eckerdal, J (in press). Information sources at play: the apparatus of knowledge production in contraceptive counselling. Journal of Documentation.

Rivano Eckerdal, J (2011). To jointly negotiate a personal decision: a qualitative study on information literacy practices in midwifery counselling about contraceptives at youth centres in Southern Sweden. Information Research, 16(1) paper 466. Retrieved 16.4.2011 at WWW: http://nformationR.net/ir/16-1/ paper466.html

Sadler, B \& Given, L (2007). Affordance theory: a framework for graduate students' information behaviour. Journal of Documentation, 63(1), 115-141.

Savolainen, R \& Kari, J (2004). Placing the Internet in information source horizons. A study of information seeking by Internet users in the context of self-development. Library \& Information Science Research, 26(4), 415-433.

Sonnenwald, DH, Wildemuth, BM, \& Harmon, GT (2001). A research method to investigate information seeking using the concept of information horizons: an example from a study of lower socio-economic student's information seeking behaviour. The New Review of Information Behaviour Research, 2, 65-86.

Sundby, J, Svanemyr, J, \& Maehre, T (1999). Avoiding unwanted pregnancy — the role of communication, information and knowledge in the use of contraception among young Norwegian women. Patient Education and Counseling, 38, 11-19.

Sundin, O (2008). Negotiations on information seeking expertise: a study of web-based tutorials for information literacy. Journal of Documentation, 64(1), $22-44$.

Sundin, O \& Francke, H (2009). In search of credibility: pupils' information practices in learning environments. Information Research, 14(4) paper 418. Retrieved 16.4.2011 at WWW: http://InformationR. net/ir/14-4/paper418.html 
Säljö, R (1999). Learning as the use of tools: a sociocultural perspective on the human-technology link. In: K Littleton \& P Light (Eds.), Learning and computers: analysing productive interactions (pp. 144166). London: Routledge.

Talja, S (2005). The social and discursive construction of computing skills. Journal of the American Society for Information Science and Technology, 56(1), 13-22.

Talja, S \& Lloyd, A (2010). Integrating theories of learning, literacies and information practices. In: A Lloyd \& S Talja (Eds.), Practising information literacy: bringing theories of learning, practice and information literacy together ( $\mathrm{pp}$. ix-xx). Wagga Wagga: Centre for Information Studies.
Tuominen, K, Savolainen, R \& Talja, S (2005). Information literacy as a sociotechnical practice. $\mathrm{Li}$ brary Quarterly, 75, 329-345.

umo.se (2011) The online youth friendly clinic. Retrieved 16.4.2011 att WWW: http://www.umo.se/ UMO---the-online-youth-friendly-clinic/

Wertsch, JV (1998). Mind as action. New York, NY: Oxford University Press.

Wilson, P (1983). Second-hand knowledge: an inquiry into cognitive authority. Westport, CT: Greenwood Press. 